DOI: https://doi.org/10.31933/jemsi.v3i3

Received: 11 November 2021, Revised: 17 Desember 2021, Publish: 1 Januari 2022

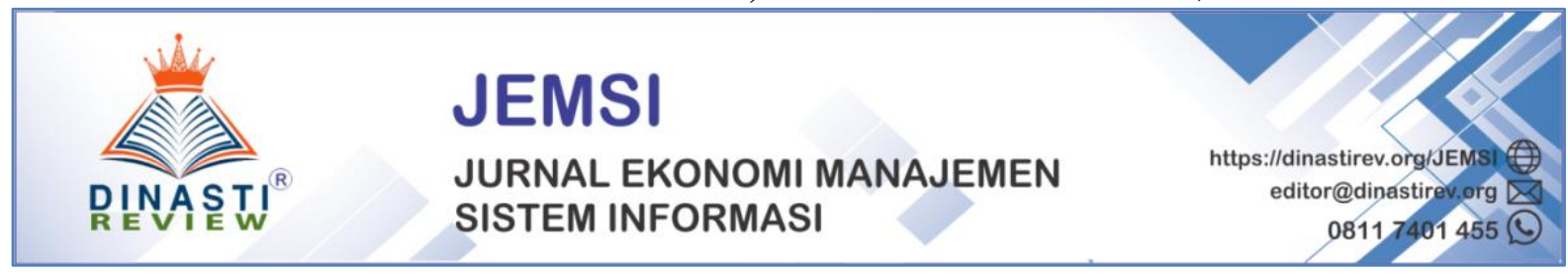

\title{
PENTINGNYA PERANAN KOMUNIKASI DALAM ORGANISASI: LISAN, NON VERBAL, DAN TERTULIS (LITERATURE REVIEW MANAJEMEN)
}

\author{
Dita Puspitasari ${ }^{1}$ Bayu Putra Danaya ${ }^{2}$ \\ 1) Mahasiswa Program Sarjana Fakultas Ekonomi dan Bisnis, Universitas Bhayangkara \\ Jakarta Raya, email: ditapsari60@ gmail.com \\ 2) Mahasiswa Program Sarjana Fakultas Ekonomi dan Bisnis, Universitas Bhayangkara \\ Jakarta Raya, email: bayudny@gmail.com
}

\section{Korespondensi Penulis: Dita Puspitasari ${ }^{1}$}

\begin{abstract}
Abstrak: Dalam suatu organisasi diperlukan adanya komunikasi, karena komunikasi terjadi ketika seseorang ingin menyampaikan informasi kepada orang lain. Informasi yang disampaikan dapat membuat orang lain memiliki persamaan maupun perbedaan maknanya. Persamaan dan perbedaan tersebut disebabkan oleh persepsi mereka yang terlibat dalam proses komunikasi. Pokok masalah yang diajukan pada artikel ini adalah masalah komunikasi yang ada pada sebuah organisasi. Komunikasi di dalam organisasi tentunya berbeda dengan komunikasi yang dilakukan di khalayak/masyarakat, selain faktor situasi kemampuan komunikasi juga disesuaikan dengan kondisi/keadaan yang terjadi di masyarakat. Masalah komunikasi dalam organisasi biasanya terjadi pada karyawan atau orang-orang yang bersangkutan pada perusahaan itu. Tujuan penulisan artikel ini guna membangun hipotesis pengaruh antar variabel untuk digunakan pada riset selanjutnya.
\end{abstract}

Kata Kunci: Komunikasi, Lisan, Non Verbal, dan Tertulis

\section{PENDAHULUAN}

\section{Latar Belakang Masalah}

Pada ilmu komunikasi kita kenal dengan komunikasi organisasi, yaitu proses penyampaian pesan ataupun pertukaran pesan yang terjadi pada suatu organisasi. Suatu organisasi bisa berjalan dengan baik jika bagian - bagian dalam organisasi tersebut bisa berkomunikasi dengan baik tentang tugas, fungsi dan tujuan organisasi tersebut. Setiap organisasi pasti akan berusaha semaksimal mungkin mengembangkan organisasinya yang dapat menjamin tercapainya tujuan yang telah ditentukan organisasi tersebut. Salah satu cara yang paaling tepat untuk mencapai tujuan organisasi tersebut yaitu ditingkatkannya atau dikembangkannya komunikasi dalam suatu organisasi tersebut. 
Komunikasi merupakan sebuah tindakan untuk berbagi informasi, gagasan maupun pendapat dari setiap partisipan komunikasi yang ada. Tindakan ini dilakukan dalam banyak konteks, yaitu dalam konteks antarpribadi, kelompok, massa serta dalam lingkungan organisasi. Komunikasi yang terjalin baik merupakan faktor penunjang untuk pencapaian sutau tujuan.

Di sebuah Lingkungan perusahaan akan terasa lebih menyenangkan, jika setiap anggotanya dapat memberikan aspirasi secara positif kepada top management atau rekan kerja lainnya. Tetapi jangan salah, bukan hanya bawahan saja yang perlu dapat berkomunikasi dengan baik. Akan tetapi semua anggota yang bekerja dalam suatu perusahaan tersebut dituntut supaya mempunyai kemampuan komunikasi.

Lingkungan kerja yang positif menaikkan produktivitas perusahaan. Semakin bagus cara berkomunikasi dalam organisasi maka semakin bagus juga sistem yang diterapkan di dalamnya. Sudah banyak organisasi yang berhasil mengembangkan bisnis yang dijalani karena memiliki cara berkomunikasi dan memahami gaya komunikasi yang bagus dan baik.

\section{Rumusan Masalah}

Berdasarkan latar belakang, maka dapat di rumuskan permasalahan yang akan dibahas guna membangun hipotesis untuk riset selanjutnya yaitu:

1. Apakah Komunikasi Lisan berpengaruh terhadap kegiatan suatu organisasi

2. Apakah Komunikasi Non-Verbal berpengaruh terhadap kegiatan suatu organisasi

3. Apakah Komunikasi Tertulis berpengaruh terhadap kegiatan suatu organisasi

\section{KAJIAN PUSTAKA}

\section{Komunikasi dalam Organisasi}

Komunikasi merupakan suatu bagian penting yang tidak dapat dipisahkan dari kehidupan manusia sebagai makhluk sosial. Secara etimologis, istilah komunikasi berasal dari bahasa latin "communicare" yang artinya "menyampaikan". Dapat dipahami bahwa pengertian komunikasi ialah suatu penyampaian informasi, baik itu pesan, ide, serta gagasan, dari satu pihak ke pihak lainnya yang dilakukan secara langsung maupun tidak langsung. (Achmad, 2014)

Menurut Achmad (2014:65) komunikasi adalah proses pemindahan serta pertukaran pesan, dimana pesan ini bisa berbentuk fakta, gagasan, perasaan, data atau informasi dari seseorang kepada orang lain. Kebanyakan pekerjaan yang dilakukan dalam suatu tim diselesaikan dengan cara independen, saling bergantung dan menyangkut komunikasi di antara anggota-anggotanya. Karena itu efektivitas komunikasi memainkan peran penting dalam memilih sesuatu yaitu apakah terdapat keuntungan atau kerugian pada proses komunikasi (Achmad, 2014)

Komunikasi menunjukan proses yang mana informasi dikirimkan dan dipahami antara dua orang atau lebih (Shane, 2010). Penekanan pada kata dipahami karena mengirimkan arti yang dimaksudkan sender yaitu esensi komunikasi yang baik. Sedangkan Menurut Sutrisno (2017:17) komunikasi merupakan suatu konsep yang multi makna. Makna komunikasi dapat 
dibedakan berdasarkan Komunikasi untuk proses sosial Komunikasi pada makna ini ada dalam konteks ilmu sosial. Dimana para ahli ilmu sosial melakukan penelitian dengan memakai pendekatan komunikasi yang secara umum menfokuskan pada aktivitas manusia dan kaitan pesan dengan perilaku.

Kegiatan komunikasi dapat dilakukan dengan dua cara, yaitu:

a. Secara langsung, yaitu dengan lisan sehingga memudahkan kedua belah pihak bisa saling mengerti.

b. Secara tidak langsung, yaitu melalui media tertentu, seperti bahasa tubuh, tulisan, telepon, televisi dan lain - lainnya.

\section{Komunikasi Lisan}

Komunikasi verbal diartikan sebagai komunikasi tatap muka dengan menggunakan mulut (lisan) dalam penyampaian informasi ketika berbicara dengan rekan kerja seperti tatap muka, rapat, dan percakapan melalui telepon (Rasmiyatun, 2021)

Proses komunikasi di dalam sekolah sebagai institusi yang menyelenggarakan pendidikan adalah komunikasi internal, yang arah komunikasinya dapat bersifat: a) vertical (dari atas ke bawah atau dari bawah ke atas), yaitu komunikasi antara kepala sekolah dengan guru atau kepala sekolah dengan staf tata usaha; b) horizontal, yaitu komunikasi antara guru dengan guru; guru dengan guru; dan c) diagonal, yaitu komunikasi antara guru dengan staf tata usaha. Didalam komunikasi antarpribadi guru dan juga siswa sangat diperlukan adanya sikap keterbukaan satu sama lain, empati, berpikir positif, dukungan dan kesetaraan diantara keduanya, dan komunikasi yang seperti itulah yang bisa meminimalisir kesenjangan diantara pengajar dan peserta didik, meminimalisir saling tidak percaya dan menaikkan rasa ingin tau siswa dan termotivasi dalam belajar. (Rasmiyatun, 2021)

Faktor lain yang dapat mempengaruhi kepuasan kerja seoarng guru dalam menjalankan tugas adalah lingkungan kerja yaitu segala sesuatu yang ada di sekitar guru, yang dapat mempengaruhi dirinya dalam melaksanakan tugas. Lingkungan kerja yang nyaman dan aman akan membuat guru juga ikut merasa nyaman dalam bekerja sehingga tugas yang dikerjakan oleh para guru juga bisa dilaksanakan dengan baik dan itu mempengaruhi kepuasan kerja guru. Berdasarkan fenomena tersebut di atas maka penelitian ini bertujuan untuk mengkaji hubungan antara kerelasian, komunikasi, lingkungan kerja, dan kepuasan kerja guru taman kanak-kanak di Kecamatan Bungbulang Kabupaten Garut. (Rasmiyatun, 2021)

Penelitian kedua ini yaitu Jenis penelitian kualitatif dengan memakai metode deskriptif. Jenis penelitian ini ialah penelitian kualitatif dengan menggunakan metode deskriptif. Menurut Moeleong (2010:7), penelitian kualitatif artinya penelitian yang tidak mengadakan perhitungan. Penelitian ini jauh lebih mementingkan proses daripada hasil. Hal itu dikarenakan bagian-bagian yang sedang diteliti akan lebih terlihat jelas jika diamati dari proses penelitiannya, bukan dari hasilnya. Data dalam penelitian ini berupa tuturan-tuturan lisan pejabat legislatif dan anggota partai tingkat Provinsi Sumatera Barat. Sang pejabat atau anggota partai dalam bertutur dalam situasi formal sudah semestinya menggunakan kosa kata 
yang baku. Hal tersebut karena mereka merupakan representasi dari orang-orang yang memiliki integritas yang baik menurut pandangan masyarakat. Selain itu, kosa kata yang yang mereka gunakan harus pula mudah dimengerti oleh lawan tutur. (Mona, 2019)

Dalam bahasa Indonesia ada kata baku Menurut Ermanto dan Emidar (2015: 91), kata baku digunakan dalam ragam bahasa formal, sedangkan dalam bahasa Indonesia ragam tidak formal, boleh menggunkan kata non baku. Dalam penelitian ini, pejabat yang diteliti tuturannya dalam kegiatan formal adalah pejabat legislatif dan anggota partai tingkat Provinsi Sumatera Barat ketika berada di acara resmi. Berdasarkan hasil penelitian yang dilakukan ditemukan sebanyak 131 kata baku dan 19 kata tidak baku. (Ermanto, 2015)

\section{Komunikasi Non Verbal}

Komunikasi non verbal adalah bahasa tubuh seperti kelipan non-verbal mata. duduk berdekatan, dan cara memandang menjadi sebuah pesan yang terlihat efektif dan mudah dipahami. (Chrisdina, 2018)

Komunikasi nonverbal adalah komunikasi yang pesannya dikemas dalam bentuk tanpa kata-kata. Non verbal juga bisa diartikan sebagai yang secara sengaja dikirimkan dan diinterpretasikan seperti tujuannya dan memiliki kemungkinan akan adanya feed back dari penerimanya. Komunikasi non verbal dapat berupa lambang-lambang seperti gerak tubuh, warna, mimik wajah dan lain - lain. (Kusumawati, 2016)

Komunikasi nonverbal memiliki kedudukan yang penting. Banyak sekali ditemukan komunikasi verbal yang tidak efektif hanya karena komunikatornya tidak menggunakan komunikasi nonverbal dengan baik dalam waktu bersamaan. Melalui komunikasi nonverbal, orang bisa mengambil suatu kesimpulan tentang berbagai macam perasaan orang, baik rasa senang, benci, sayang, rindu dan berbagai macam perasaan lainnya. Kaitannya dengan dunia bisnis, komunikasi nonverbal bisa membantu komunikator untuk lebih memperkuat pesan yang disampaikan dan juga memahami reaksi komunikan saat menerima pesan. (Kusumawati, 2016)

Bentuk komunikasi nonverbal, diantaranya adalah; bahasa isyarat, ekspresi wajah, sandi, simbol-simbol, pakaian seragam, warna dan intonasi suara. Berikut ini adalah beberapa contoh komunikasi nonverbal:

a. Sentuhan, Sentuhan dapat termasuk: bersalaman, menggenggam tangan, sentuhan di punggung, mengelus-elus, dan lain-lain.

b. Gerakan Tubuh, Dalam komunikasi nonverbal, gerakan tubuh meliputi kontak mata, ekspresi wajah, isyarat, dan sikap tubuh. Gerakan tubuh biasanya digunakan untuk menggantikan suatu kata atau frase.

c. Vokalik, atau biasa disebut dengan paralanguage, adalah unsur nonverbal dalam suatu ucapan, yaitu cara berbicara.

d. Kronemik, adalah bidang bersangkutan yang mempelajari penggunaan waktu dalam komunikasi nonverbal. Penggunaan waktu dalam komunikasi nonverbal mencakup durasi yang dianggap pas untuk suatu aktivitas, banyaknya aktivitas yang dianggap layak dilakukan dalam jangka waktu tertentu, serta ketepatan waktu. (Kusumawati, 2016) 
Dalam komunikasi non verbal ini mengunakan teori penelitian pengaruh perencanaan kerja dan komunikasi terhadap kinerja karyawan. Perencanaan terhadap kinerja karyawan merupakan penentuan tujuan perusahaan dan kemudian menyajikan dengan jelas strategistrategi, taktik-taktik dan operasi diperlukan untuk mencapai tujuan perusahaan secara menyeluruh. Peningkatan perencanaan sangat ditentukan oleh besarnya peran indikator yang membentuknya, yakni: (a) penetapan tujuan organisasi yang jelas, (b) mendefinisikan situasi sekarang untuk mencapai keberhasilan, (c) mengenal dukungan dan kendala untuk mengatasi persoalan kerja, (d) mengembangkan premis perencanaan dengan membuat peramalan rencana, (e) mengembangkan metode pengawasan operasi rencana yang efektif. Hasil penelitian membuktikan bahwa perencanaan memberikan dampak positif dan signifikan terhadap kinerja karyawan, yang berarti perencanaan kerja yang baik akan menimbulkan kinerja karyawan akan baik pula. Penelitian ini juga membuktikan bahwa penelitian yang dilakukan oleh Sudirman (2011) dan Rosliani Kadir (2011), perencanaan berpengaruh signifikan terhadap kinerja karyawan. (Ajmal, 2018)

Komunikasi terhadap kinerja karyawan merupakan hubungan pengertian antara pihak yang satu dengan pihak yang lain, sehingga apa yang dikomunikasikan dapat dimengerti, dipikirkan yang akhirnya dapat terlaksanakan. Adanya pengaruh signifikan dari variabel komunikasi terhadap kinerja karyawan sangat ditentukan oleh besarnya peran indikator yang membentuk variabel tersebut, yakni: (a) Memiliki rasa percaya diri dalam memulai komunikasi, (b) Mendapat Pendidikan / pelatihan mengenai komunikasi, (c) Berusaha menjalankan instruksi dengan baik, (d) Mampu memberikan saran dengan tepat saat berkomunikasi, dan (e) Bersedia menerima kritik dengan baik saat berkomunikasi. Hasil penelitian membuktikan bahwa komunikasi membawa pengaruh positif dan signifikan terhadap kinerja karyawan, yang berarti semakin baik komunikasi, maka kinerja karyawan akan semakin meningkat pula. Penelitian ini juga membuktikan penelitian yang dilakukan oleh Husein Anwar (2010), Sudirman (2011), dan Suryadi (2011) bahwa komunikasi yang baik dalam organisasi akan meningkatkan kinerja pegawai. (Ajmal, 2018)

\section{Komunikasi Tertulis}

Menurut Subarna (2007), Komunikasi tertulis adalah proses penyampaian pesan komunikasi yang ditulis menggunakan kata-kata dalam bentuk tulisan. Komunikasi tertulis ialah komunikasi yang dilakukan melalui sebuah tulisan yang dilakukan dalam kegiatan surat menyurat melalui pos, telegram, telexaf, fax, e-mail dan sebagainya. (Kusumawati, 2016)

Dalam komunikasi tertulis ini menggunakan penilitian kemampuan komunikasi matematis siswa lamban belajar dalam menyelesaikan sebuah soal bangun datar. Konflik yang dihadapi siswa lamban belajar ialah dari segi komunikasi, baik komunikasi secara lisan maupun tulisan. Pembelajaran matematika sulit dikomunikasikan sebab terbentur pada simbol-simbol yang sifatnya abstrak (Supriadi, 2017). Banyak dari siswa lamban belajar yang mengalami kesulitan dari segi pengucapan atau lisan serta tulisan. Seperti yang terjadi di dalam kelas siswa tidak bisa mengucapkan kembali apa yang diucapkan oleh guru, mereka cenderung hanya mengikuti teman-temannya yang dianggap bisa. Sedangkan untuk komunikasi tertulis siswa tidak bisa menulis dengan benar dan juga ada siswa yang tidak mau 
menulis sama sekali, hal ini yang mengakibatkan bahwa kemampuan komunikasi siswa lamban belajar tergolong belum lancar. (Nanang, 2016)

Teknik pengambilan sample yang digunakan peneliti yaitu teknik purposive sampling (Sugiono, 2009). Teknik ini ditentukan dengan tujuan dan alasan tertentu dari penelitian yang diambil. Partisipan yang akan diwawancarai dan diamati dalam penelitian ini dipilih karena mereka ialah orang - orang yang terlibat secara langsung dengan penelitian yang diteliti di sekolah tersebut. Subjek yang ditentukan dalam penelitian yaitu sebanyak 5 orang siswa kelas V SD Negeri 1 Sukamaju Abung semuli Lampung Utara. Instrumen penelitian ini berbentuk tes dan wawancara, instrumen tes digunakan untuk mengukur kemampuan komunikasi tertulis siswa lamban belajar (slow learner) sedangkan wawancara digunakan buat megetahui kemampuan komunikasi lisan siswa yang lamban belajar. Ada beberapa faktor yang mempengaruhi komunikasi tulis siswa terganggu, antara lain yaitu banyak siswa siswa yang kurang konsentrasi dalam mengerjakan soal, situasi kelas yang kurang kondusif, serta jam pelajaran yang sudah hampir habis, hal ini menyebabkan siswa tidak dapat mengerjakan soal dengan benar dan terburu- buru. Dari data tersebut dapat di ambil kesimpulannya bahwa anak lamban belajar mempunyai masalah pada komunikasi tulisnya. (Nanang, 2016)

Dilihat dari analisis jawaban siswa tersebut baik menggunakan tes maupun wawancara penulis menyimpulkan bahwa siswa lamban belajar mempunyai masalah dari segi komunikasi, baik komunikasi tertulis maupun komunikasi lisan. Akan tetapi jika dibandingkan dengan keduanya yaitu antara komunikasi tertulis dan komunikasi lisan siswa yang lebih baik yaitu komunikasi tertulis, hal ini dikarenakan siswa yang menjawab benar jauh lebih banyak dibandingkan jawaban siswa yang menjawab benar dalam komunikasi lisan. (Nanang, 2016)

Dalam penilitian kedua teori yang digunakan dalam penelitian ini yaitu teori efektivitas e-mail menurut Paul Hewwit (2006). Pengumpulan data pada penelitian ini melalui tahapan observasi, penyebaran kuesioner, studi dokumentasi, kepustakaan dan internet untuk mendapatkan data tentang efektivitas e-mail sebagai media komunikasi internal terhadap kepuasan komunikasi karyawan. Dengan media e-mail karyawan cukup menerima informasi bermanfaat tentang kebijakan organisasi yakni berupa surat edaran (SE), informasi penting lainnya dan membantu karyawan menyelesaikan pekerjaan. Namun walapun hasilnya valid untuk pertanyaan e-mail membantu karyawan memahami peran dengan baik tetapi ada juga pengaruh adanya peran dari komunikasi internal lainnya dengan baik pula serta perlu adanya keterlibatan karyawan dalam organisasi supaya karyawan lebih memahami lagi peran mereka dengan baik. kesimpulannya bahwa Efektifitas email sebagai media internal mempunyai pengaruh yang kuat. (Uswatun Hasannah, 2018)

Tabel 1 : Penelitian Terlebih Dahulu

\begin{tabular}{|c|c|c|c|c|}
\hline No & Author (Tahun) & Hasil Riset & $\begin{array}{c}\text { Persamaan Dengan Artikel } \\
\text { Ini }\end{array}$ & $\begin{array}{c}\text { Perbedaan Dengan } \\
\text { Artikel Ini }\end{array}$ \\
\hline
\end{tabular}




\begin{tabular}{|c|c|c|c|c|}
\hline 1 & $\begin{array}{l}\text { Rasmiyatun } \\
\text { (2021) }\end{array}$ & $\begin{array}{l}\text { Kerelasian, Komunikasi, } \\
\text { Dan Lingkungan Kerja } \\
\text { Meningkatkan Kepuasan } \\
\text { Kerja Guru Taman Kanak- } \\
\text { Kanak Kecamatan } \\
\text { Bungbulang Garut }\end{array}$ & $\begin{array}{l}\text { Persamaannya yaitu dengan } \\
\text { adanya komunikasi lisan dapat } \\
\text { meningkatkan kepuasan dalam } \\
\text { bekerja atau pun berkegiatan } \\
\text { lainnya }\end{array}$ & $\begin{array}{l}\text { Terletak pada kerelasian, } \\
\text { dan lingkungan kerja dapat } \\
\text { meningkatkan kepuasan } \\
\text { kerja. }\end{array}$ \\
\hline 2 & Mona (2019) & $\begin{array}{l}\text { Performa Pemilihan } \\
\text { Kosakata Baku Dalam } \\
\text { Komunikasi Lisan Oleh } \\
\text { Pejabat Legislatif Dan } \\
\text { Tokoh Partai Tingkat } \\
\text { Provinsi Sumatera Barat }\end{array}$ & $\begin{array}{l}\text { Menjelaskan tentang memilih } \\
\text { kosakata yang baku agar } \\
\text { menjadi komunikasi yang baik } \\
\text { dan benar }\end{array}$ & $\begin{array}{l}\text { Berfokus lebih } \\
\text { mementingkan proses } \\
\text { daripada hasil. Hal itu } \\
\text { dikarenakan bagian-bagian } \\
\text { yang sedang diteliti akan } \\
\text { lebih terlihat jelas jika } \\
\text { diamati dari proses } \\
\text { penelitiannya, bukan dari } \\
\text { hasilnya. }\end{array}$ \\
\hline 3 & Nanang (2016) & $\begin{array}{l}\text { Analisis Kemampuan } \\
\text { Komunikasi Matematis } \\
\text { Siswa Lamban Belajar } \\
\text { Dalam Menyelesaikan } \\
\text { Soal Bangun Datar }\end{array}$ & $\begin{array}{l}\text { sama - sama tidak ada yang } \\
\text { dapat berperan dengan } \\
\text { komunikasi tertulis. }\end{array}$ & $\begin{array}{l}\text { Tertuju mengalami } \\
\text { kesulitan dari segi } \\
\text { pengucapan atau lisan serta } \\
\text { tulisan. }\end{array}$ \\
\hline 4 & $\begin{array}{l}\text { Kusumawati, T } \\
\text { (2016) }\end{array}$ & Komunikasi Nonverbal & $\begin{array}{l}\text { Menjelaskan bahwa } \\
\text { komunikasi nonverbal dapat } \\
\text { berupa lambang-lambang } \\
\text { seperti gerak tubuh, warna, } \\
\text { mimik wajah dan lain - lain. }\end{array}$ & $\begin{array}{l}\text { Tertuju melalui } \\
\text { komunikasi nonverbal, } \\
\text { orang bisa mengambil } \\
\text { suatu kesimpulan tentang } \\
\text { berbagai macam perasaan } \\
\text { orang, baik rasa senang, } \\
\text { benci, sayang, rindu dan } \\
\text { berbagai macam perasaan } \\
\text { lainnya }\end{array}$ \\
\hline 5 & Ajmal (2018) & $\begin{array}{l}\text { Pengaruh Perencanaan } \\
\text { Kerja Dan Komunikasi } \\
\text { Terhadap Kinerja } \\
\text { Karyawan }\end{array}$ & $\begin{array}{l}\text { Menguraikan tentang } \\
\text { Komunikasi dalam organisasi } \\
\text { harus memiliki perencanaan } \\
\text { agar mempuyai tujuan yang } \\
\text { jelas }\end{array}$ & $\begin{array}{l}\text { Tidak adanya pengaruh } \\
\text { signifikan dari variabel } \\
\text { komunikasi terhadap } \\
\text { kinerja karyawan }\end{array}$ \\
\hline
\end{tabular}




\begin{tabular}{|c|c|c|c|c|}
\hline 6 & Uswatun (2018) & $\begin{array}{l}\text { Efektivitas E-Mail Sebagai } \\
\text { Media Komunikasi } \\
\text { Internal Terhadap } \\
\text { Kepuasan Komunikasi } \\
\text { Karyawan }\end{array}$ & $\begin{array}{l}\text { Menjelaskan bahwa dalam } \\
\text { penelitian ini harus memiliki } \\
\text { media komunikasi internal, } \\
\text { karena dalam organisasi } \\
\text { komunikasi ga harus lisan } \\
\text { tetapi juga harus dibutuhkan } \\
\text { komunikasi tertulis sebagai } \\
\text { sebuah bukti dalam } \\
\text { komunikasi. }\end{array}$ & $\begin{array}{l}\text { Perbedaanya yaitu dengan } \\
\text { media e-mail karyawan } \\
\text { cukup menerima informasi } \\
\text { bermanfaat tentang } \\
\text { kebijakan organisasi yakni } \\
\text { berupa surat edaran (SE), } \\
\text { informasi penting lainnya } \\
\text { dan membantu karyawan } \\
\text { menyelesaikan pekerjaan. }\end{array}$ \\
\hline
\end{tabular}

\section{METODE PENULISAN}

Metode penulisan artikel ilmiah ini adalah dengan metode kualitatif dan kajian pustaka (Library Research). Mengkaji teori dan hubungan atau pengaruh antar variabel dari bukubuku dan jurnal baik secara off line di perpustakaan dan secara online yang bersumber dari Mendeley, Scholar Google dan media online lainnya.

Dalam penelitian kualitatif, kajian pustaka harus digunakan secara konsisten dengan asumsi-asumsi metodologis. Artinya harus digunakan secara induktif sehingga tidak mengarahkan pertanyaan-pertanyaan yang diajukan oleh peneliti. Salah satu alasan utama untuk melakukan penelitian kualitatif yaitu bahwa penelitian tersebut bersifat eksploratif, (Ali \& Limakrisna, 2013).

\section{HASIL DAN PEMBAHASAN}

Artikel ini menganalis dan membahas tentang faktor - faktor komunikasi yang terjadi dalam organisasi yaitu : Komunikasi Lisan Yang Tidak Baik Berpengaruh Pada Lawan Bicaranya, komunikasi non verbal dapat berpengaruh terhadap kegiatan suatu organisasi, komunikasi tertulis dapat berpengaruh terhadap kegiatan suatu organisasi. Berikut pembahasannya :

\section{Pengaruh Komunikasi Lisan terhadap Komunikasi dalam Organisasi}

Menurut Dipodjojo (1982), komunikasi lisan merupakan kegiatan individu dalam upaya menyampaikan sebuah pesan secara lisan kepada individu lain, sekelompok orang, yang disebut audience ataupun majelis.

Tim yang solid merupakan tim yang senantiasa bekerja sama apapun pekerjaan yang wajib dituntaskan dari pimpinan demi kepentingan perusahaan. Membangun tim yang solid tersebut perlu pendekatan yang tepat. Pendekatan dapat dicoba melalui komunikasi yang baik. Kemudian kebalikannya komunikasi yang tidak sehat dalam perusahaan dapat memunculkan konflik antar anggota. Baik itu konflik dalam urusan individu ataupun urusan pembagian tugas dalam perusahaan. Bila telah demikian tidak akan terdapat lagi sebutan yang namanya tim solid. Tim akan terpecah jadi beberapa kubu sehingga memunculkan kelompok- kelompok yang saling menghujat ataupun membenci. Permasalahan ini sangat beresiko dalam urusan internal perusahaan sebab dapat merambat pada hasil kinerja karyawan jadi menurun atau bahkan bener - bener menjadi kurang baik.

\section{Pengaruh Komunikasi Non-Verbal terhadap Komunikasi dalam Organisasi}


Menurut Resberry (2004), Komunikasi Non - Verbal adalah suatu tindakan serta sikap manusia yang memiliki makna.

Pada contoh kasus komunikasi non verbal bisa terjadi pada Saat operator jahit memproduksi pakaian lalu membutuhkan benang jahit, maka operator mengangkat tangan untuk dibawakan benang jahit tambahan. Agar kegiatan produksi berjalan baik. Kasus lainnya juga bisa di gimik muka atau ekspresi, ketika kita memasang ekspresi tidak senyum maka orang yang kita temui akan menganggap bahwa kita tidak menyukai orang tersebut yang di temui. Memasang muka senyum terhadap orang yang ditemui termasuk komunikasi non verbal yang baik karena seseorang yang ditemui akan menganggap bahwa anda adalah orang yang ramah atau murah senyum, dengan begitu pertemuaannya akan terjalin baik.

\section{Pengaruh Komunikasi Tertulis terhadap Komunikasi dalam Organisasi.}

Menurut Subarna (2000) Komunikasi tertulis yaitu suatu proses penyampaian pesan komunikasi dengan memakai kata-kata dalam bentuk tulisan.

Pada setiap perusahaan pasti akan adanya sebuah dokumen - dokumen tertulis karena jika tidak adanya dokumen maka akan terjadinya kesalah pahaman dan juga kalau tidak adanya dokumen yang tersedia maka tidak ada bukti jika adanya kesalahan. Seperti kasus di sebuah bengkel mobil yang besar, tidak adanya dokumen atau data - data perincian ataupun bukti - bukti tertulis. Jadi perusahaan tersebut sering terjadi korupsi dengan karyawannya karena tidak adanya data tertulis secara rinci atas uang masuk dan Untuk bukti membeli suatu barang seperti bon - bon pembelian tidak ada, maka mudah terjadinya kebohongan Dan akan membuat kesalahpahaman karena bisa saja karyawan yang dituduh korupsi belum tentu dia pelakunya karna tidak ada bukti - bukti yang tadi sebutkan.

\section{Conceptual Framework}

Sesuai dengan rumusan masalah penulisan artikel ini serta kajian studi literature baik yang bersumber dari buku atau google dan artikel yang relevan, maka di peroleh kerangka artikel seperti di bawah ini.

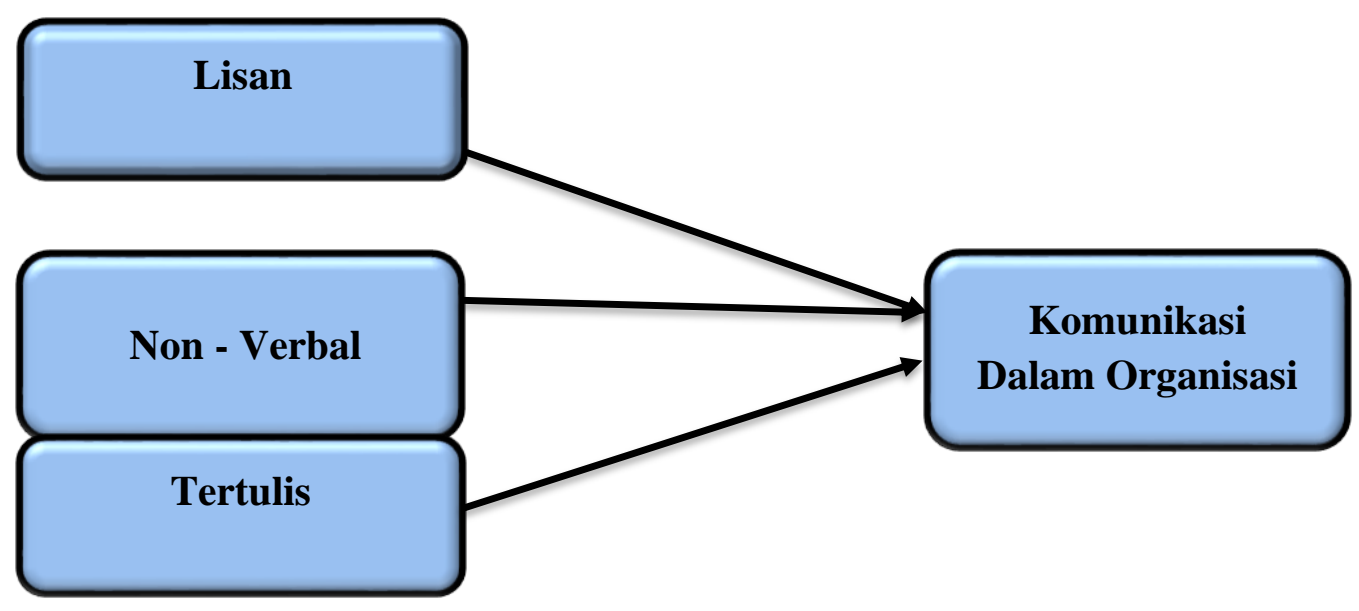

Gambar 1 : Conceptual Framework 
Berdasarkan Kajian teori dan review hasil dari artikel yang relevan serta gambar dari conceptual framework, maka: toleransi, kesalahpahaman, dan perilaku individual berpengaruh terhadap komunikasi dalam perusahaan.

Selain dari variabel exogen ini yang mempengaruhi Komunikasi Dalam Perusahaan, masih banyak variabel lain yang mempengaruhinya diantaranya adalah:

a) Kompetensi: (Ansori \& Ali, 2017), and (Ridwan et al., 2020).

b) Kreativitas: (Desfiandi et al., 2017), (Yacob et al., 2020), (Richardo et al., 2020), (Christina Catur Widayati et al., 2020), (Prayetno \& Ali, 2020b), (C.C. Widayati et al., 2020).

c) Budaya: (Purba et al., 2017), (Brata et al., 2017), (Harini et al., 2020), (Elmi et al., 2016).

d) Pengetahuan:(Desfiandi et al., 2017), (Prayetno \& Ali, 2020a), (Mukhtar et al., 2016), (Brata, Husani, Hapzi, Baruna Hadi Shilvana AliBrata, Husani, Hapzi, 2017), and (Toto Handiman \& Ali, 2019).

\section{KESIMPULAN DAN SARAN \\ Kesimpulan}

Berdasarkan teori, artikel yang relevan dan pembahasan maka dapat di rumuskan hipotesis untuk riset selanjutnya:

1. Komunikasi Lisan berpengaruh terhadap Komunikasi dalam organisasi. Agar tidak adanya kesalahpahaman antar tenaga kerja yang dapat menyebabkan kerugian,

2. Komunikasi Non Verbal berpengaruh terhadap Komunikasi dalam organisasi. Gestur tubuh karyawan akan terlihat dan apabila karyawan duduk tegak saat menyampaikan ide kepada atasan, maka karyawan tersebut orang yang optimis

3. Komunikasi Tertulis berpengaruh terhadap Komunikasi dalam organisisasi. Apabila terdapat penambahan jam kerja / lembur dan target yang harus dicapai. Maka disini komunikasi tertulis sangat berperan.

\section{Saran}

Berdasarkan pembahasan di atas, maka pada saran ini yaitu harus adanya komunikasi yang baik mau itu komunikasi lisan, non verbal dan tertulis. Karena komunikasi yang baik sangat penting untuk kehidupan manusia di lingkungan rumah, sekolah, bahkan dalam sebuah organisasi. Seperti halnya komunikasi lisan jika kita menggunakan bahasa yang baku dan sopan maka lawan bicara kita akan merespon kita dengan baik juga dan dapat merasa nyaman dalam komunikasi secara langsung.

\section{DAFTAR RUJUKAN}

Afzali, A., Motahari, A. A., \& Hatami-Shirkouhi, L. (2014). Investigating the influence of perceived organizational support, psychological empowerment and organizational Zraková, Diana. (2017). Influence of Information-communication System to Reputation Management of a Company. Procedia Engineering

Ansori, A., \& Ali, H. (2017). Analisis Pengaruh Kompetensi Dan Promosi Terhadap Kinerja Pegawai Negeri Sipil Pada Sekretariat Daerah Kabupaten Bungo. Jurnal Ilmiah Universitas Batanghari Jambi. https://doi.org/10.33087/jiubj.v15i1.198 
Brata, Husani, Hapzi, Baruna Hadi Shilvana AliBrata, Husani, Hapzi, B. H. S. A. (2017). Saudi Journal of Business and Management Studies CoBrata, Husani, Hapzi, Baruna Hadi Shilvana AliBrata, Husani, Hapzi, B. H. S. A. (2017). Saudi Journal of Business and Management Studies Competitive Intelligence and Knowledge Management: An Analysis of t. Saudi Journal of Business and Management Studies. https://doi.org/10.21276/sjbms

Brata, B. H., Husani, S., \& Ali, H. (2017). a Comparative Study on Development Off Small and Medium Enterprises (Smes) in Japan and Malaysia. Saudi Journal of Business and Management Studies. https://doi.org/10.21276/sjbms

Borchers, Nils S. (2021). Managing strategic influencer communication: A systematic overview on emerging planning, organization, and controlling routines. Public Relations Review

Cho, Moonhee. (2021). When an organization violates public expectations: A comparative analysis of sustainability communication for corporate and nonprofit organizations. Public Relations Review

Desfiandi, A., Fionita, I., \& Ali, H. (2017). Implementation of the information systems and the creative economy for the competitive advantages on tourism in the province of Lampung. International Journal of Economic Research.

Elmi, F., Setyadi, A., Regiana, L., \& Ali, H. (2016). Effect of leadership style, organizational culture and emotional intelligence to learning organization: On the Human Resources Development Agency of Law and Human Rights, Ministry of Law and Human Rights. International Journal of Economic Research.

Falkheimer, Jesper. (2017). Is Strategic Communication too important to be left to Communication Professionals?: Managers' and coworkers' attitudes towards strategic communication and communication professional. Public Relations Review

Harini, S., Hamidah, Luddin, M. R., \& Ali, H. (2020). Analysis supply chain management factors of lecturer's turnover phenomenon. International Journal of Supply Chain Management.

Kharouf, Husni. (2020). Understanding online event experience: The importance of communication, engagement and interaction. Journal of Business Research

Mukhtar, Risnita, Saifillah, M. S., \& Ali, H. (2016). Effect of knowledge management and work commitment to employees satisfaction services (Study on teacher Madrasah Aliyah Country Jambi Province). International Journal of Economic Research.

Prayetno, S., \& Ali, H. (2020a). Entrepreneurial supply chain management competence: Predictors of work motivation advocate. International Journal of Supply Chain Management.

Prayetno, S., \& Ali, H. (2020b). The influence of work motivation, entrepreneurship knowledge and advocate independence on advocate performance. International Journal of Innovation, Creativity and Change.

Purba, C. B., Arzio, \& Ali, H. (2017). The influence of compensation, working environment and organization culture on working productivity of BPJS (workers social security agency) employment staff in Rawamangun Branch. Man in India.

Richardo, Hussin, M., Bin Norman, M. H., \& Ali, H. (2020). A student loyalty model: 
Promotion, products, and registration decision analysis-Case study of griya english fun learning at the tutoring institute in wonosobo central Java. International Journal of Innovation, Creativity and Change.

Ridwan, M., Mulyani, S. R., \& Ali, H. (2020). Building behavior and performance citizenship: Perceived organizational support and competence (case study at SPMI private university in west Sumatra). International Journal of Psychosocial Rehabilitation. https://doi.org/10.37200/IJPR/V24I6/PR260195

Salmon, Charles T. (2019). Third-person effect in the context of public relations and corporate communication. Public Relations Review

Seitz, Stephanie R. (2021). Stuttering: Stigma and perspectives of (dis)ability in organizational communication. Human Resource Management Review

Toto Handiman, U., \& Ali, H. (2019). The Influence of Brand Knowledge and Brand Relationship On Purchase Decision Through Brand Attachment. In International Journal of Business Marketing and Management (IJBMM).

Widayati, C.C., Ali, H., Permana, D., \& Nugroho, A. (2020). The role of destination image on visiting decisions through word of mouth in urban tourism in Yogyakarta. International Journal of Innovation, Creativity and Change, 12(3).

Widayati, Christina Catur, Ali, H., Permana, D., \& Nugroho, A. (2020). The role of destination image on visiting decisions through word of mouth in urban tourism in Yogyakarta. International Journal of Innovation, Creativity and Change.

Yacob, S., Sucherly, Sari, D., Mulyana, A., \& Ali, H. (2020). An Optimising strategy for minimarket modern retail business performance in Indonesia. International Journal of Innovation, Creativity and Change. 